\title{
REMOVAL OF CADMIUM FROM CONTAMINATED SOIL USING IRON (III) OXIDE NANOPARTICLES STABILIZED WITH POLYACRYLIC ACID
}

\author{
Malihe MOHAMADIUN ${ }^{1}$, Behnaz DAHRAZMA ${ }^{2, *}$, Seyed Fazlolah SAGHRAVANI ${ }^{3}$, \\ Ahmad KHODADADI DARBAN ${ }^{4}$ \\ 1, 2, ${ }^{3}$ Department of Civil Engineering, Shahrood University of Technology, postal code: 3619995161-316, \\ Shahrood, Iran \\ ${ }^{4}$ Department of Engineering and Technology, Tarbiat Modares University, Jalal AleAhmad St., 14115-111, \\ Tehran, Iran
}

Received 11 October 2016; accepted 03 August 2017

\begin{abstract}
The aim of this study is to evaluate the effect of Fe3O4 nanoparticle, stabilized with polyacrylic acid on cadmium removal from the contaminated soils. To investigate the effect of important parameters, including nanoparticle concentration, $\mathrm{pH}$, contact time, and the ratio of contaminated soil mass to nanofluid volume, several batch tests were performed. The maximum removal rate $(100 \%)$ of cadmium was obtained in the following conditions: nanofluid concentration = $500 \mathrm{ppm}, \mathrm{pH}=6.5$, contact time $=24 \mathrm{hr}$ and the ratio of contaminated soil mass $(\mathrm{gr})$ to nanofluid volume $(\mathrm{mL})=1: 150$. Results of selective sequential extraction tests showed that the distribution of cadmium in different fractions of the soil was carbonates, oxides and hydroxides, residual fraction, exchangeable, and organic matter respectively. The tendency of nanoparticles for removal of $\mathrm{Cd} 2+$ from the soil fractions was in the order of: exchangeable $>$ carbonates $>$ oxides and hydroxides $>$ organic matter $>$ residual.
\end{abstract}

Keywords: soil contamination, iron (III) oxide nanoparticle, polyacrylic acid, cadmium removal, selective sequential extraction.

\section{Introduction}

One of the early generations of nanoscale technologies in the field of environment is iron nanoparticle technology (Wang, Zhang 1997). Medical treatment (medical devices), military installation, pollution sensing and detection, ecosystem monitoring and green chemistry are from important technologies in which nanotechnology has been applied effectively. Remediation/decontamination of pollutants in soils and groundwater has received significant benefit from nanotechnology. More researches are necessary to achieve the safe and beneficial applications of this new technology due to its novelty (Reddy 2010).

Many nanoscale metal oxides such as $\mathrm{AgO}_{2}$, which is expensive, are toxic and unsuitable for injection into the environment, while nanoscale iron particles (NIP) with their environmentally-benign characteristics, favorable chemistry, relatively low cost, and ease of use are considered excellent candidate for environmental decontamination (Reddy 2010; Yuan et al. 2012).

With rapid urbanization and industrial development particularly by the beginning of the twentieth century, heavy metal pollution in the biosphere has now become one of the most serious environmental concerns due to its severe long-term implications on human health and the environment. Some of the heavy metals such as $\mathrm{Zn}, \mathrm{Fe}$, and $\mathrm{Cu}$ are essential for human metabolism but, at higher concentrations, can also lead to poisoning. Some others such as $\mathrm{Cd}$ and $\mathrm{Pb}$ are more dangerous hence, their concentrations should be as closest to zero as possible $(\mathrm{Oz}-$ turk et al. 2017). Recently, several researches were done on dangerous effects of heavy metals including $\mathrm{Mg}, \mathrm{Fe}, \mathrm{Cd}$, $\mathrm{Zn}$, and $\mathrm{Cu}$ and their removal techniques (Vasarevičius et al. 2016; Strachel et al. 2017). Cd has high mobility and is accepted as carcinogenic element. Cd accumulation in plants causes adverse effects leading to growth inhibition and even death; it is also a potentially carcinogenic heavy metal, which can accumulate in human organs, so removal of this heavy metal from soil could be one of the environmentally valuable aspects of this study.

In recent decades, nanoparticles were used to remove heavy metals from contaminated water and wastewater.

*Corresponding author. E-mail: behnaz_dahrazma@shahroodut.ac.ir 
Cadmium ion removal by adsorption onto nano zerovalent iron (NZVI) particles from contaminated water sources and aqueous solutions (Boparai et al. 2011; Guler 2016) and for water treatment (Crane, Scott 2012) was studied. Use of $\mathrm{Fe}_{3} \mathrm{O}_{4}$ magnetic nanoparticles (MNPs) modified with 3-aminopropyltriethoxysilane (APS), copolymers of acrylic acid (AA), and crotonic acid (CA) for removal of heavy metal ions from water (Ge et al. 2012) are from researches which have proved effectiveness of using nano iron particles (NIP) for water, wastewater.

Soil washing is a common method for soil treatment. Different agents were employed for removal of heavy metals from contaminated soil. Soil washing with acetic acid and EDTA were applied on contaminated soils for $\mathrm{Cd}$ removal (Li et al. 2010; Gzar et al. 2014). NZVI has the capacity to remove all cadmium from contaminated soil (Shafai et al. 2012). Effect of soil washing with chelators or in combination with ferric chloride on heavy metals removal from soil was also studied (Guo et al. 2016).

There is lack of literatures for using nanoparticles as washing agent to remove heavy metals from contaminated soil. Recently, Adsorption of trace elements form contaminated soil with application of nano-maghemite (NM) (iron nano-oxide; $\mathrm{Fe}_{2} \mathrm{O}_{3}$ ) (Martínez-Fernández et al. 2014), assessment the effects of NZVI on heavy metal removal from calcareous soil (Shafai et al. 2012) and using NZVI for Cr (VI) removal from contaminated soil (Di Palma et al. 2015) were studied.

There are various methods to produce iron nanoparticles. In the recent years, several synthetic methods have been developed through various researches (Wang, Zhang 1997; Zhang 2003; Sun et al. 2006; Liu et al. 2015).

Many studies have been conducted to modify the nanoparticle surface properties (Elliott, Zhang 2001; Xu et al. 2005), and enhance the efficiency for field delivery and reactions (Elliott, Zhang 2001; Kanel et al. 2007). These extensive laboratory studies have demonstrated that nanoscale iron particles are effective for the transformation of a wide array of common environmental contaminants such as chlorinated organic solvents (Wang, Zhang 1997; Elliott, Zhang 2001; Zhang 2003; Nutt et al. 2005), organochlorine pesticides (Cao et al. 2003), Polychlorinated biphenyls (PCBs) (Zhang 2003; He, Zhao 2005), organic dyes (Liu et al. 2005), various inorganic compounds and metal ions such as $\mathrm{As}(\mathrm{III}), \mathrm{Pb}(\mathrm{II}), \mathrm{Cu}(\mathrm{II}), \mathrm{Ni}(\mathrm{II})$ and $\mathrm{Cr}$ (VI) (Alowitz, Scherer 2002; Xu et al. 2005).

Due to variation in the composition of the soils, including heterogeneous mixtures of organic and inorganic substances, the binding mechanisms for heavy metals are very different (Tokalioglu et al. 2003). This fact influences the bioavailability of heavy metals in the environment (Tessier et al. 1979). Identification of the adsorption procedure of trace elements on the several fractions of soils and sediments are important for designing the removal protocol. Selective sequential extraction (SSE) is widely used for this purpose (Tessier et al. 1979; Huang et al. 2012, 2016). Selective sequential extraction methods have been used for assessment of several heavy metals removal from soils, sediments, compost, sludge and wastewater and also the mobility of these metals have also been studied (Mulligan, Dahrazma 2003; Dahrazma, Mulligan 2006; Hseu 2006; Fan et al. 2012; Zaleckas et al. 2013; Zak et al. 2013; Uduma, Jimoh 2013; Ozbas, Balkaya 2014; Zhao et al. 2014; Pandey et al. 2015).

Varieties of SSE procedures are now available (Filgueiras et al. 2002; Gleyzes et al. 2002). The first SSE procedure was introduced by Crawford and McLaren in 1973 in order to remove elements from exchangeable, residual, organic, and oxides fractions of natural soil (McLaren, Crawford 1973). BCR (Community Bureau of Reference) and Tessier are from most common SSE methods (Tessier et al. 1979; Rico et al. 2009; Huang et al. 2012, 2016). The BCR procedure was proposed by European Union. $\mathrm{BCR}$ sequential extraction procedure has been widely applied to soil and sediment samples (terrestrial or marine originated) (Tokalioglu et al. 2003; Doelsh et al. 2008). According to Tessier procedure, heavy metals could be extracted from five fractions of soils and sediments, namely exchangeable, carbonate, iron and manganese oxides, organic matter, and residual (Tessier et al. 1979). This procedure has also been applied for heavy metal extraction in many studies (Quezada-Hinojosa et al. 2015a, 2015b). This procedure has been adapted and improved by Yong (Yong et al. 1993). The Yong's method is considered as the most complete SSE procedure that has been implemented in many researches for determination of heavy metals removal mechanism (Dahrazma, Mulligan 2007; Uduma, Jimoh 2013). The procedure, could determine concentration of heavy metals in six soil fractions namely, soluble, exchangeable, carbonates, oxides and hydroxides, organic matter, and residual fraction.

Considering the efficiency of nanoscale iron particles in heavy metal removals from aqueous solutions, water and wastewater, and also lack of comprehensive studies on heavy metals removal from soils using nanotechnologies, this research focused on the use of the iron (III) oxide nanoparticle for removal of cadmium from contaminated soil. The Yong's method of SSE was adopted in this study in order to assess the performance of iron nanoparticles on contaminated soil.

\section{Material and method}

\subsection{Material}

\subsubsection{Soil mixture}

To ensure the absence of other pollutants and elimination of any interaction between soil pollutants, after several trials and errors, based on the common natural soil compositions, the soil was prepared with clean standard materials as listed below:

- 161 Firuzkooh Sand (8\%);

- Silt was prepared by Soil Mechanics Laboratory of Tehran University (40\%); 
- Kaolinite was prepared byIran China Clay Industries Co. (10\%);

- Organic matter (10\%);

- Red mud, which was excavated from a 2 meter depth pristine in the vicinity of the Shahrood City and passed through the sieve number $200(20 \%)$;

- $\mathrm{CaCo}_{3}$ (Merck Co.) (10\%);

- $\mathrm{CaO}$ (Sigma Aldrich Co.) (2\%).

\subsubsection{Nanoparticles}

Iron (III) Oxide Nanoparticles were produced in Pasteur Institute of Iran with $99.5 \%$ purity and average particle size of $44.5 \mathrm{~nm}$.

\subsubsection{Material for SSE}

All chemicals for SSE procedure including $\mathrm{MgCl}_{2}$, $\mathrm{C}_{2} \mathrm{H}_{3} \mathrm{NaO}_{2}, \mathrm{C}_{2} \mathrm{H}_{7} \mathrm{NO}_{2}, \mathrm{H}_{6} \mathrm{ClNO}, \mathrm{HNO}_{3}, \mathrm{H}_{2} \mathrm{O}_{2}, \mathrm{HCl}$ and Acetic Acid were obtained from Merck Co.

\section{Material for Cd spectrophotometric determination}

All chemicals including $\mathrm{Cd}(\mathrm{NO} 3)_{2}$ (Merck Co.), Ammonium Pyrrolidine dithiocarbamate (APDC) (Sigma Aldrich Co.), and Tween 80 (Sigma Aldrich Co.) were of guaranteed laboratory grade reagents.

\subsection{Experimental procedures}

\subsubsection{Preparation of contaminated soil}

The makeup soil was mixed with $500 \mathrm{ppm}$ solution of cadmium nitrate for $48 \mathrm{~h}$ on a shaker with $80 \mathrm{rpm}$. To ensure the complete mixing, the ratio of the solution $(\mathrm{mL})$ to the weight of the soil (gr) was 20:1. Then, the soil was removed from the solution. Using centrifuge $(3500 \mathrm{rpm}$ for $20 \mathrm{~min}$ ) to remove all unabsorbed contaminant from the soil, this stage was repeated with distilled water. The soil was dried at the room temperature. The prepared soil was used for the course of this research.

\subsubsection{Soil structure}

After soil preparation, the contaminated soil was sieved according to ISIRI 4977. The result is shown in Figure 1. More than 54\% of soil passed the Sieve No. 400 (opening size: $0.037 \mathrm{~mm}$ ). This part was analyzed with Laser Particle Sizer ANALLISETE 22 (FRITISH Co.). The result is presented in Figure 2.

According to the results of sieve analyses, based on the American Association of State Highway and Transportation Officials (AASHTO) soil classification, the percentages of sand and silt were 29, and 17 respectively. Also, according to the laser particle analyses, the amount of the silt and clay were $41 \%$ and $13 \%$ respectively. Therefore, the grain size distribution was $29 \%$ sand, $58 \%$ silt and $13 \%$ clay.

\subsubsection{Preparation of the nanofluid}

For preparation of homogeneous nanofluid, the iron (III) oxide nanoparticles were stabilized with polyacrylic acid (PAA) (Sigma Aldrich Co.), according to the procedure

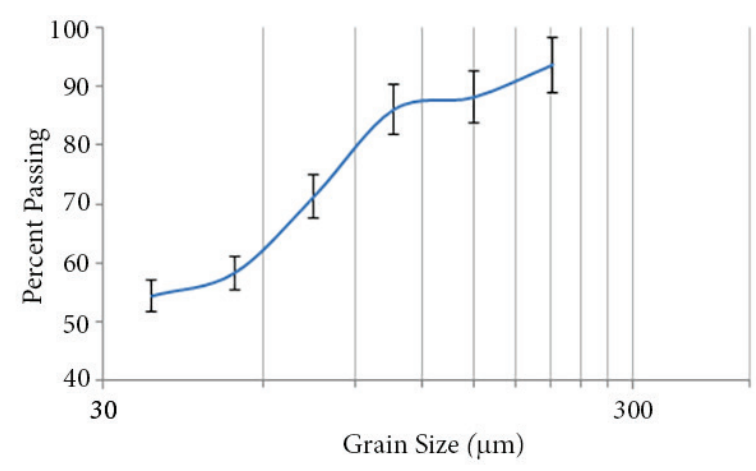

Figure 1 . The size distribution of the contaminated soil by sieving

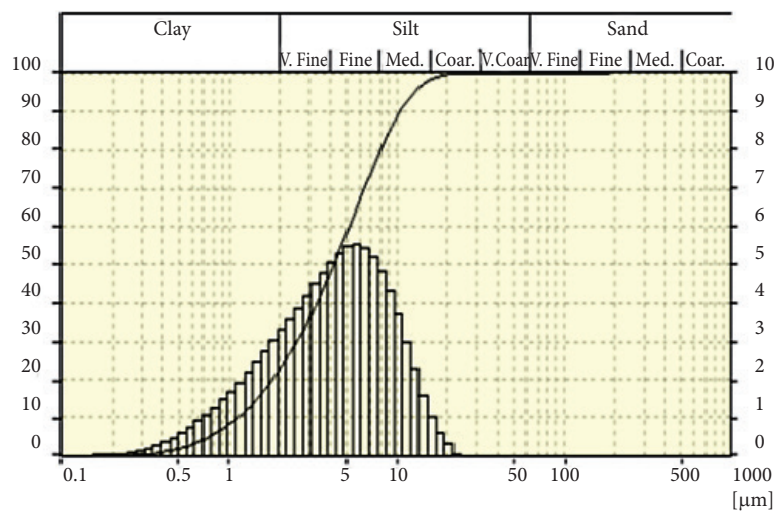

Figure 2. Results of laser particle sizing for the soil

proposed by Golzar et al. (Golzar et al. 2014). Accordingly, specified value of the nanoparticles in the one-fifth of the final solution volume distilled water is placed in ultrasonic bath $(40 \mathrm{KHz}, 50 \mathrm{~W})$ for $30 \mathrm{~min}$. In the other flask, PAA (the weight ratio of PAA to nanoparticle is 2:1) was mixed with the four-fifth of the final volume distilled water at the speed of $500 \mathrm{rpm}$ for one hour. These two solutions were mixed together and placed in ultrasonic bath $(40 \mathrm{KHz}$, $50 \mathrm{~W}$ ), for one hour. So for preparation of one liter of $500 \mathrm{ppm}$ nanofluid $0.5 \mathrm{~g}$ of NIP in $200 \mathrm{~mL}$ distilled water was placed in ultrasonic bath and $1 \mathrm{~g}$ of PAA was solved in $800 \mathrm{~mL}$ distilled water, afterwards these two solutions were mixed and placed in ultrasonic bath again. Then this combination was kept in the room temperature for $24 \mathrm{~h}$. The solution was placed in the same ultrasonic bath for 30 min each time prior to applying to the soil.

\subsubsection{Determination of heavy metal content of the soil}

To find the concentration of heavy metals in the soil, it was digested by the method recommended by Environment Canada (1990). According to this method $1.0 \mathrm{~g}$ of the soil was placed in a $1 \mathrm{~L}$ beaker; $100 \mathrm{~mL}$ of $16 \mathrm{~N}$ nitric acid were added to the beaker over a minimum period of 2 minutes; $40 \mathrm{~mL}$ of $\mathrm{H}_{2} \mathrm{O}_{2}$ (30\%) were added to the beaker; the beaker was left for 5 minutes to react; the beaker was placed on a hot plate (Fisher Stirring Hotplate) until it boiled. Then, it was removed from the heat and cooled 
to the room temperature; $200 \mathrm{~mL}$ aqua regia $(50 \mathrm{~mL} \mathrm{HCl}$,

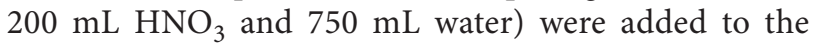
beaker; the beaker was filled to the $500 \mathrm{~mL}$ level with distilled water; the solution was prepared for analysis (Dahrazma, Mulligan 2007). The Cd content was measured at $9500 \mathrm{mg} \cdot \mathrm{Kg}^{-1}$.

\subsubsection{Soil washing procedure}

The soil was washed with nanofluid iron oxides in a batch configuration. To achieve the ultimate $\mathrm{Cd}$ removal by iron (III) oxide nanoparticle, the effective parameters including the nanofluid concentration, $\mathrm{pH}$, contact time, and the ratio of the nanofluid $(\mathrm{mL})$ to contaminated soil (gr) were evaluated and optimized. For this purpose $1.5 \mathrm{gr}$ of soil was washed with nanofluid with different concentrations from 100 to $2000 \mathrm{ppm}$. After determination of optimized nanofluid concentration, $\mathrm{pH}$ was optimized in the range of 5 to 10 . In the next stage contact time from 5 to 14400 minute was examined at the nanofluid concentration and $\mathrm{pH}$ which were determined in the first stage to achieve the maximum removal. Finally, soil was washed with different ratio of mass of soil to the volume of nanofluid in the range of 1:2 to $1: 150$ at the condition with the most removal in the previous steps of the test. All the tests were triplicated. The difference between test results never exceeded more than $5 \%$. Parameters were optimized step by step and results of each step were used for the next parameter. All the tests were performed at $25^{\circ} \mathrm{C}$.

The soil was placed in batch reactors and nanofluid iron oxide was added to the soil for $\mathrm{Cd}^{2+}$ removal. The samples were placed on a rotary shaker for a desired period of time. For analysis, the soils were separated from the solutions by centrifuge ( $3500 \mathrm{rpm}$ for $20 \mathrm{~min}$ ). The supernatant solutions were then decanted from the soils and the concentration of $\mathrm{Cd}^{2+}$ in solutions was measured using UV spectrophotometer.

\subsubsection{Selective sequential extraction tests}

The procedure used for the batch sequential extraction was similar to that of Yong et al. (1993) shown in the Table 1 Soil samples $(1.5 \mathrm{~g})$ were washed with the nanoparticle solutions and controls (Yong et al. 1993; Dahrazma, Mulligan 2006). Each fraction was collected and the concentrations of cadmium were determined by UV spectrophotometer according to the procedure presented in the next section. After each step, samples were washed with distilled water for the next step and then subsequently dried prior to next step. The amounts of $\mathrm{Cd}^{2+}$ extracted from each of the extractions were then determined and the percentage extracted by each solution was calculated.

\subsubsection{Spectrophotometric determination of cadmium}

UV Spectrophotometer (CECIL CE 7000 Series) was employed to measure the concentration of cadmium using APDC complexes in Tween 80 media. The detection limit for good linearity was $0.05 \mathrm{mgL}^{-1}$ and the maximum
Table 1. Sequential extraction process (adapted from Yong et al. 1993)

\begin{tabular}{|c|c|c|}
\hline $\begin{array}{c}\text { Se- } \\
\text { quence }\end{array}$ & Chemical Reagents & Fraction \\
\hline 1 & $\begin{array}{l}\text { Overnight extraction of metals by } \\
\text { nanoparticle solution and controls } \\
\text { (distilled water) with } 15 \mathrm{~mL} \text { of solution }\end{array}$ & Soluble \\
\hline 2 & $\begin{array}{l}\text { Extraction of metals with } 8 \mathrm{~mL} \text { of } 1 \\
\mathrm{M} \mathrm{MgCl}_{2}(\mathrm{pH} 7) \text { for } 1 \mathrm{~h}\end{array}$ & Exchangeable \\
\hline 3 & $\begin{array}{l}\text { Extraction of metals with } 8 \mathrm{~mL} \text { of } \\
1 \mathrm{M} \mathrm{NaOAc} \text { adjusted to } \mathrm{pH} 5 \text { with } \\
\text { acetic acid for } 5 \mathrm{~h}\end{array}$ & Carbonates \\
\hline 4 & $\begin{array}{l}\text { Extraction of metals with } 20 \mathrm{~mL} \text { of } \\
0.04 \mathrm{M} \mathrm{NH}_{2} \mathrm{OH} . \mathrm{HCl} \text { in } 25 \%(\mathrm{v} / \mathrm{v}) \\
\text { acetic acid }(\mathrm{pH} 2.5) \text { at } 96^{\circ} \mathrm{C} \text { for } 6 \mathrm{~h}\end{array}$ & $\begin{array}{l}\text { Oxides and } \\
\text { hydroxides }\end{array}$ \\
\hline 5 & $\begin{array}{l}\text { Extraction with } 3 \mathrm{~mL} \text { of } 0.02 \mathrm{M} \\
\mathrm{HNO}_{3} \text { and } 5 \mathrm{~mL} \text { of } 30 \% \mathrm{H}_{2} \mathrm{O}_{2}(\mathrm{pH} \\
\text { 2) for } 2 \mathrm{~h} \text { at } 85^{\circ} \mathrm{C} \text {, followed by } 3 \mathrm{~mL} \\
\text { of } 30 \% \mathrm{H}_{2} \mathrm{O}_{2}(\mathrm{pH} 2) \text { at } 85^{\circ} \mathrm{C} \text { for } 3 \mathrm{~h} \\
\text { and then } 5 \mathrm{~mL} \text { of } 3.2 \mathrm{M} \mathrm{NH}_{4} \mathrm{OAc1} \text { in } \\
20 \%(\mathrm{v} / \mathrm{v}) \mathrm{HNO}_{3} \text { diluted to } 20 \mathrm{~mL} \text { at } \\
\text { room temperature for } 30 \mathrm{~min} \text {. }\end{array}$ & $\begin{array}{l}\text { Organic } \\
\text { matter }\end{array}$ \\
\hline 6 & $\begin{array}{l}\text { Digestion at } 90{ }^{\circ} \mathrm{C} \text { with } 25 \mathrm{~mL} \text { of } \\
\text { dilute aqua regia }(50 \mathrm{~mL} \mathrm{HCl}, 200 \mathrm{~mL} \\
\left.\mathrm{HNO}_{3} \text { and } 750 \mathrm{~mL} \text { water }\right) \text { for } 3 \mathrm{~h}\end{array}$ & $\begin{array}{l}\text { Residual } \\
\text { fraction }\end{array}$ \\
\hline
\end{tabular}

wavelength of $\mathrm{Cd}^{2+}$ complex appeared at $324 \mathrm{~nm}$ (Lee, Choi 2001). Standard $\mathrm{Cd}^{2+}$ solutions were made from $1000 \mathrm{mgL}^{-1}$ stock solutions. A $1.0 \%(\mathrm{w} / \mathrm{v})$ Tween 80 solution was prepared by dissolving $1.0 \mathrm{~g}$ of Tween 80 in $100 \mathrm{~mL}$ of water with stirring. Phosphate buffer $(\mathrm{pH}=7.0)$ was prepared by appropriately mixing $0.1 \mathrm{M} \mathrm{KH}_{2} \mathrm{PO}_{4}$ and $0.1 \mathrm{M} \mathrm{NaOH}$. Since APDC gradually decomposes in aqueous solution, $0.1 \%$ APDC solution was made whenever needed (Lee, Choi 2001).

Standard $\mathrm{Cd}^{2+}$ solutions were prepared in the range of $0.5-2.5 \mathrm{mgL}^{-1}$ in $10 \mathrm{~mL}$ volumetric flasks. $0.5 \mathrm{~mL}$ of APDC and $1 \mathrm{~mL}$ of Tween 80 were added to each standard solution of $\mathrm{Cd}^{2+}$ and $1 \mathrm{~mL}$ of sample. The solutions were then filled up to $10 \mathrm{~mL}$ with phosphate buffer. Blank solution was also prepared by the above procedure without $\mathrm{Cd}$ solution. After 20 minutes, the cadmium concentration could be determined by a UV-Vis spectrophotometer (Lee, Choi 2001). By measuring the $\mathrm{Cd}^{2+}$ concentration, the mass of $\mathrm{Cd}^{2+}$ and the percentage of removal of $\mathrm{Cd}^{2+}$ by nanofluid was calculated based on the initial total content of $\mathrm{Cd}^{2+}$ in the soil.

\section{Results and discussion}

\subsection{Effective parameters for Cd removal}

The results of soil washing procedures and investigation on the effect of different parameters in $\mathrm{Cd}^{2+}$ removal using iron oxide nanoparticles are presented below.

\footnotetext{
1 Ac denotes acetate.
} 


\subsubsection{Effect of nanoparticles concentration}

$1.5 \mathrm{gr}$ of soil was washed with the blank (distilled water) and nanofluid of different concentrations, 100, 300, 500, 1000 , and $2000 \mathrm{ppm}$. Other parameters were constant $(\mathrm{pH}=8.5$, contact time $=24 \mathrm{hr})$. The results are shown in Figure 3. The results of removal by distilled water are not shown since cadmium was detected in the final solution.

Results illustrated that, removal rate directly increased by increasing the concentration of nanofluid up to $19 \%$, which occurred at $2000 \mathrm{ppm}$. As shown in Figure 3, the $\mathrm{Cd}^{2+}$ sorption rate was positively correlated with nanofluid concentration. In higher concentrations, higher amount of nanoparticle existed, so more sorption sites were found. Since the nanoparticles were coated with PAA, the higher concentrations are not practical due to intense increase in the viscosity of the solution. The concentration of 500 ppm with removal rate of $11 \%$ was selected to continue, for the sake of workability of the solution.

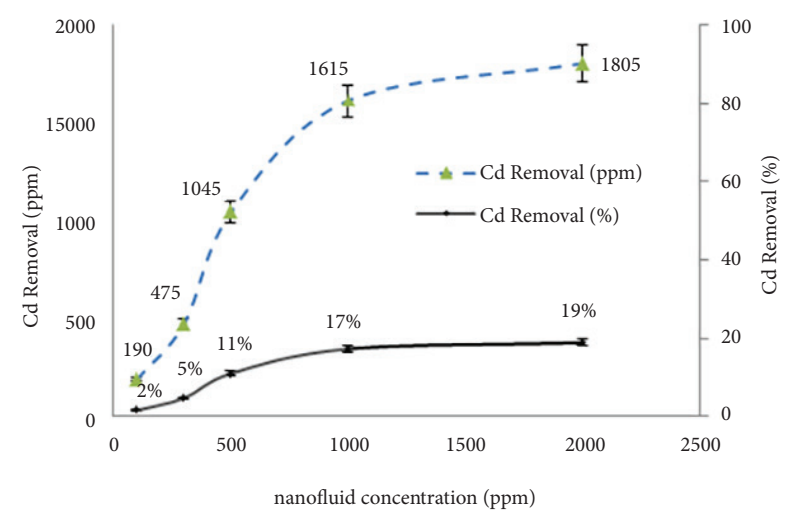

Figure 3. Removal of Cd by nanofluid at different concentrations $(\mathrm{pH}=8.5$, ratio of soil mass (gr) to nanofluid volume $(\mathrm{mL})=1: 10$, Contact time $=24 \mathrm{hr})$

\subsubsection{Effect of $\mathrm{pH}$}

According to the preliminary tests, at $\mathrm{pH}=4$ and also at $\mathrm{pH}=11$ the nanofluid was unstable and settled. This is shown in Figure 4(a) and Figure 4(b). So the optimization of $\mathrm{pH}$ was performed in the range of 5 to 10 .

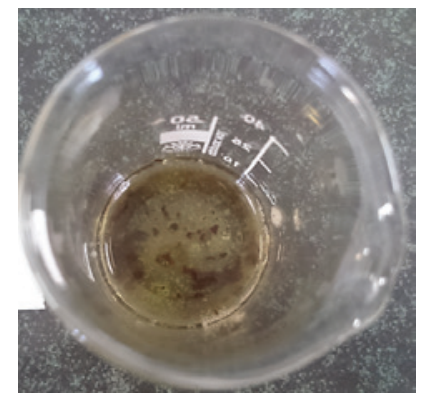

(a)

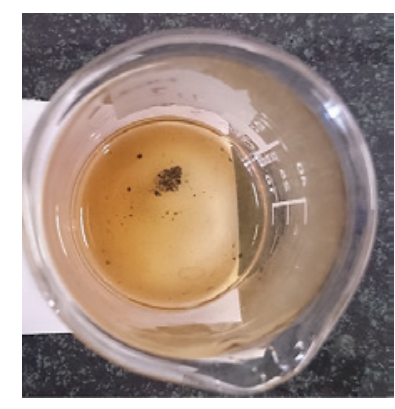

(b)
Figure 4. Nanofluid at $\mathrm{pH}=4$ (a) and $\mathrm{pH}=11(\mathrm{~b})$

For optimizing $\mathrm{pH}, 1.5 \mathrm{~g}$ of soil was washed with $15 \mathrm{~mL}$ of $500 \mathrm{ppm}$ nanofluid at pHs, including, 5 through 10, for $24 \mathrm{hr}$. The results are shown in Figure 5.

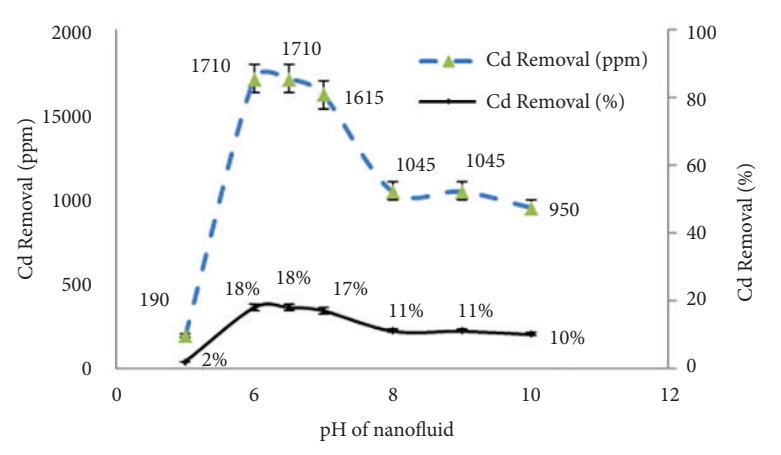

Figure 5. Removal of Cd by nanofluid at different $\mathrm{pH}$ (Concentration $=500 \mathrm{ppm}$, ratio of soil mass (gr) to nanofluid volume $(\mathrm{mL})=1: 10$, Contact time $=24 \mathrm{hr})$

As per the results, maximum $\mathrm{Cd}$ removal was recorded at $\mathrm{pH}=6(18 \%)$ and it was very similar to $\mathrm{pH}=7(17 \%)$. The percentage of removal of cadmium at $\mathrm{pH}=6.5$ was $18 \%$ too, so this $\mathrm{pH}$ was selected.

Hetzer et al. (2006) further justified this fact as well. Several other researchers affirmed that optimal $\mathrm{pH}$ for the adsorption of cadmium is situated around 6 (Asci et al. 2007; Quintelas et al. 2009). Similar results have also been presented by Chowdhury et al. (2011) in the evaluation of adsorption mechanism of dyes (Chakravarty et al. 2010), and also by Ebrahimi et al. (2015) in assessment of biosorption of $\mathrm{Cd}$ (II) from aqueous solutions.

Cd removal from the soil by nanofluid depends on both the solubility of cadmium and the properties of nanoparticles. According to the solubility curve of cadmium, by increasing the $\mathrm{pH}$, its solubility is decreased (Bradl 2005). Therefore, by reducing the solubility of the ion in nanofluid at higher $\mathrm{pH}$, separating it from the soil is also reduced.

Magnetite nanoparticles were prepared by alkaline hydrolysis of the highly concentrated mixed solution of iron(II)- and iron(III)-salts. So excess amount of proton and therewith its surface charge depends on the $\mathrm{pH}$ (Tombacz et al. 2006). Magnetite is an amphoteric solid, which can develop charges in the protonation and deprotonation reactions of $\mathrm{Fe}-\mathrm{OH}$ sites on surface. These surface reactions can be interpreted as the specific adsorption of $\mathrm{H}^{+}$- and $\mathrm{OH}^{-}$- ions at the hydrated solid/water interface (Tombacz 2002). Colloidal solution nanofluid achieve to the highly stabilized condition at the point of zero charge (PZC) where surface charge density is also zero. The PZC of nano $\mathrm{Fe}_{3} \mathrm{O}_{4}$ seems to be at $\mathrm{pH} 7.9 \pm 0.1$ (Tombacz et al. 2006). The optimum $\mathrm{pH}$ for the cadmium removal from the soil in this study (6.5) can be a result of both factors, the further Cd solubility in low $\mathrm{pH}$ and creation of a stable colloidal solution at $\mathrm{pH}$ of about 7.9.

\subsubsection{Effect of contact time}

To optimize the contact time, $1.5 \mathrm{gr}$ of soil was washed with $15 \mathrm{~mL}$ of nanofluid with concentration of $500 \mathrm{ppm}$ at $\mathrm{pH}=6.5$ for $5,10,15,60,300,720,1440,2880,4320$, and 14400 minutes. The results are shown in Figure 6. 


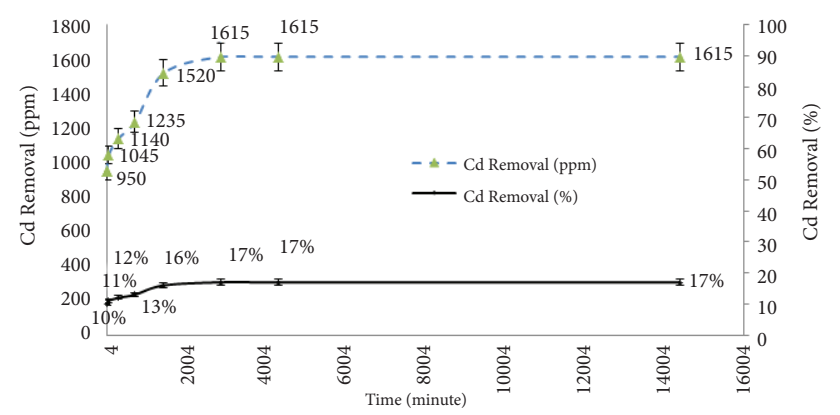

Figure 6. Removal of Cd by nanofluid at different Contact Time (Concentration $=500 \mathrm{ppm}, \mathrm{pH}=6.5$, ratio of soil mass (gr) to nanofluid volume $(\mathrm{mL})=1: 10)$

The results depicted that $\mathrm{Cd}$ removal increased considerably with increasing in contact time up to $24 \mathrm{hr}$ (from $10 \%$ at $5 \mathrm{~min}$ to $16 \%$ at $1440 \mathrm{~min}$ ). The difference was negligible between $24 \mathrm{hr}$ and $48 \mathrm{hr}$ (from 16\% at $1440 \mathrm{~min}$ to $17 \%$ at $2880 \mathrm{~min}$ ). Since a notable increment of removal was not observed after $48 \mathrm{hr}$, the $24 \mathrm{hr}$ contact time was selected to continue.

As it is shown, initially, the rate of adsorption was rapid because of the adsorption of Cd onto the exterior surface. After that, adsorption occurred relatively slow due to the entrance of $\mathrm{Cd}$ into pores (interior surface). The initial faster rates of adsorption may also be related to the presence of more binding sites for adsorption and the slower adsorption rates at the end is due to the saturation of the binding sites. Similar conclusions have been proposed by Chowdhury et al. (Chowdhury et al. 2011).

\subsubsection{Effect of the ratio of the mass of the soil to the volume of the nanofluid}

To study the effect of ratio of the soil mass (gr) to volume of the nanofluid $(\mathrm{mL}), 1.5 \mathrm{~g}$ of soils were washed with different ratio of mass of soil to the volume of nanofluid,1:2, $1: 5,1: 10,1: 20,1: 50,1: 100$, and $1: 150$ at $\mathrm{pH}=6.5$ for $24 \mathrm{hr}$. The results are shown in Figure 7. According to these experiments, increasing the ratio of nanofluid volume to the soil mass can improve the removal of cadmium up to $100 \%$ which occurred at the ratio of 1:150 (mass soil (gr) to volume of nanofluid $(\mathrm{mL})$.
With increasing the ratio of nanofluid volume to the soil mass, a higher amount of $\mathrm{Cd}$ was removed because of the increase in the dosage of adsorbent. This is due to an increase in the surface area of the adsorbent, which in turn increases the number of binding sites (Chakravarty et al. 2010). Similar result had also achieved by Nasiri et al. (2013) who assessed the effect of concentration of nanoparticle NZVI on Cd removal from each fraction of soil. Accordingly, with increasing the nanoparticles concentration, the $\mathrm{Cd}$ removal increased in different fractions of the contaminated soil.

According to these tests, the comparison between samples used as control and samples washed with nanofluid depicted that nanofluid could remove $100 \%$ of cadmium from the soil. Cadmium extraction from contaminated soil by this method is considerably effective in contrast to the available literature. For example, by Thermally Responsive Elastin (ELPEC20) Biopolymers biopolymer in soil washing experiments, up to $62 \%$ removal was achieved (Lao et al. 2007), the efficiency of cadmium removal from the soil using acetic acid was 70.6\% (Gzar et al. 2014), and $85 \%$ reduction of cadmium concentration was achieved by combination of electrokinetic remediation and soil washing technology (Giannis, Gidarakos 2005).

\subsection{Sequential Extraction Tests}

After investigation on the effect of different parameters on the removal of cadmium using iron oxide nanofluid, and optimizing the removal conditions, the tendency of iron (III) oxide nanoparticle to remove cadmium from each fraction of the soil was studied using the SSE techniques proposed by Yong in 1993 (Yong et al. 1993). For this purpose $1.5 \mathrm{~g}$ of the soil was washed with distilled water as control and the nanofluid at the following conditions: nanofluid concentration $=500 \mathrm{ppm}, \mathrm{pH}=6.5$, contact time $=24 \mathrm{hr}$, and ratio of soil mass (gr) to nanofluid volume $(\mathrm{mL})=1: 100$. According to the optimized test at the ratio of soil mass (gr) to nanofluid volume $(\mathrm{mL})=1: 150$ $\mathrm{Cd}^{2+}$ was completely removed from all fractions of soil, thus it is not possible to determine the order of tendency of nanoparticle, for removal of $\mathrm{Cd}^{2+}$ under this condition. Therefore, SSE test was done at the ratio of soil mass (gr) to nanofluid volume less than the optimized amount of this parameter. All the tests were in triplicate.

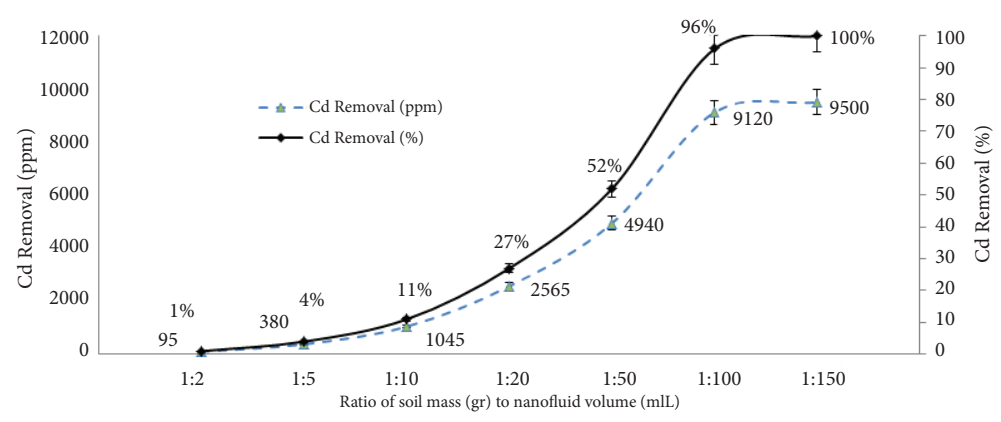

Figure 7. Removal of Cd by nanofluid with different Ratio of soil mass (gr) to volume of nanofluid (mL) (Concentration $=500 \mathrm{ppm}, \mathrm{pH}=6.5$, Contact time $=24 \mathrm{hr}$ ) 
Selective sequential extraction results on control samples showed that Cd removal didn't occur by washing the soil with distilled water. According to the results, shown in Figure 8, the accumulation of $\mathrm{Cd}$ in soil fractions was 55\% (5225 ppm) in carbonates, 30\% (2850 ppm) in oxides and hydroxides, $7.5 \%$ (712.5 ppm) in residual fraction, 5.5\% (522.5 ppm) in exchangeable, and $2 \%$ (190 ppm) in organic matter.

Selective sequential extraction also showed that $96 \%$ (9120 ppm) of Cd content was removed from soil by nanofluid (soluble fraction). According to the results (Figure 9), Cadmium was completely removed from exchangeable fraction $(522.5 \mathrm{ppm})$. The rates of removal from other fractions were $97.8 \%$ (5108.7 ppm) from carbonates, 95,3\% (2717.3 ppm) from oxides and hydroxides, 94.1\% (178.8 ppm) from organic matter, and 82.4\% (587.3 ppm) from residual fraction.

Removal from the soil fractions using iron oxide nanofluid in this study occurred as follows:

- Exchangeable: The highest removal (100\%) occurred in this fraction where cadmium completely removed. Cd content in this part changed from 5.5\% (522.5 ppm) to $0 \%$;

- Carbonate: 97.8\% (5108.7 ppm) of Cd removed from carbonate phase, and Cd content changed from 55\% (5225 ppm) to $1.2 \%$ (116.3 ppm);

- Oxides and Hydroxides: Cd removal occurred in this fraction with the mass fraction of $95.3 \%$

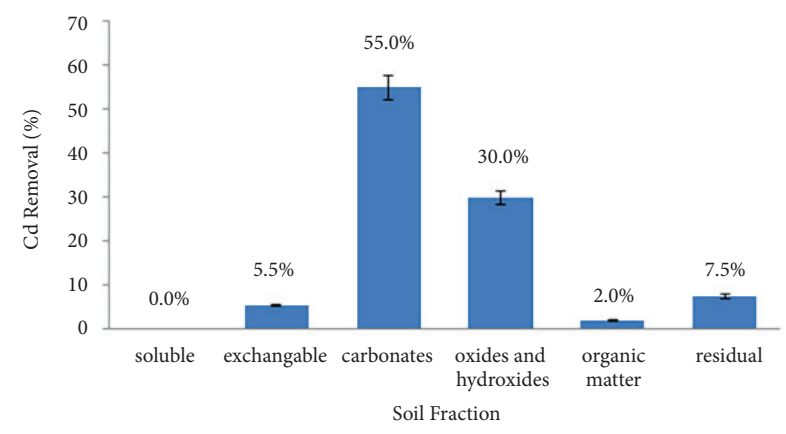

Figure 8. Sequential extraction of cadmium from contaminated soil

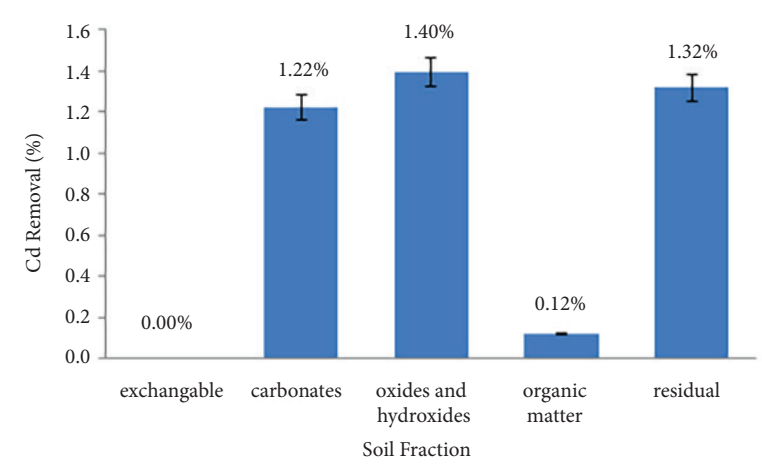

Figure 9. Sequential extraction of cadmium from contaminated soil after washing with nanofluid (Concentration $=500 \mathrm{ppm}$, $\mathrm{pH}=6.5$, Contact time $=24 \mathrm{hr}$, ratio of soil mass (gr) to nanofluid volume $(\mathrm{mL})=1: 100)$
(2717.33 ppm) and Cd content changed from 30\% (2850 $\mathrm{ppm}$ ) to $1.4 \%$ (132.67 $\mathrm{ppm})$;

- Organic matter: 94.1\% (178.8 ppm) Cd removed from this fraction of soil. In this phase, $\mathrm{Cd}$ content decreased from $2 \%$ (190 ppm) to $0.12 \%$ (11.18 ppm); - Residual: Cd removed from this part of soil with the removal rate of $82.4 \%$ (587.3 ppm). Cd content in this fraction decreased from $7.5 \%(712 \mathrm{ppm})$ to $1.32 \%$ (125.3 ppm).

\section{Conclusions}

The soil treatment procedure and $\mathrm{Cd}^{2+}$ removal from contaminated soil were affected by different parameters. According to the findings at this study, nano $\mathrm{Fe}_{3} \mathrm{O}_{4}$ stabilized with PAA could remove up to $100 \%$ of cadmium from the soil at the following optimized conditions: nanofluid concentration $=500 \mathrm{ppm}, \mathrm{pH}=6.5$, contact time $=24 \mathrm{hr}$, and the ratio of mass of soil (gr) to volume of the nanofluid $(\mathrm{mL})=1: 150$.

The results of the SSE tests on the soil samples which washed with distilled water and the nanofluid depicted that the partitioning of cadmium in different fractions of the contaminated soil before washing tests were carbonates, oxides and hydroxides, residual fraction, exchangeable, and organic matter respectively. The tendency of nano $\mathrm{Fe}_{3} \mathrm{O}_{4}$ to adsorb cadmium from different fractions of the soil and its removal rate from each fraction were in the following order:

Exchangeable $(100 \%)>$ Carbonate $(97.8 \%)>$ Oxides and hydroxides $(95.3 \%)>$ Organic Matter $(94.1 \%)>\operatorname{Re}-$ sidual $(82.4 \%)$

Therefore, it could be concluded that iron (III) oxide nanoparticle stabilized with polyacrylic acid could be used as an effective adsorbent to remove cadmium from contaminated soil.

\section{References}

Alowitz, M. J.; Scherer, M. M. 2002. Kinetics of nitrate, nitrite, and $\mathrm{Cr}$ (VI) reduction by iron metal, Environmental Science and Technology 36: 299-306. https://doi.org/10.1021/es011000h

Asci, Y.; Nurbas, M.; Sag Acikel, Y. 2007. Sorption of Cd (II) onto kaolin as a soil component and desorption of Cd (II) from kaolin using rhamnolipid biosurfactant, Jornal of Hazardous Materials B 139: 50-56.

https://doi.org/10.1016/j.jhazmat.2006.06.004

Boparai, H. K.; Joseph, M.; O'Carroll, D. M. 2011. Kinetics and thermodynamics of cadmium ion removal by adsorption onto nanozerovalent iron particles, Jornal of Hazardous Materials 186: 458-465. https://doi.org/10.1016/j.jhazmat.2010.11.029

Bradl, H. B. 2005. Heavy Metals in the Environment, Vol. 6. University of Applied Sciences Trier Neubrucke. Germany: Elsevier Academic Press.

Cao, J. S.; Elliott, D.; Zhang, W. X. 2003. Nanoscale iron particles for perchlorate reduction, in $225^{\text {th }}$ American Chemical Society National Meeting, 27 January 2003, New Orleans, LA.

Chakravarty, P.; Sen Sarmab, N.; Sarma, H. P. 2010. Biosorption of cadmium (II) from aqueous solution using heartwood powder of Areca catechu, Chemical Engineering Journal 162: 949-955. https://doi.org/10.1016/j.cej.2010.06.048 
Chowdhury, S.; Mishra, R.; Saha, P.; Kushwaha, P. 2011. Adsorption thermodynamics, kinetics and isosteric heat of adsorption of malachite green onto chemically modified rice husk, Desalination 265: 159-168.

https://doi.org/10.1016/j.desal.2010.07.047

Crane, R. A.; Scott, T. B. 2012. Nanoscale zero-valent iron: Future prospects for an emerging water treatment technology, Journal of Hazardous Materials 211-212: 112-125. https://doi.org/10.1016/j.jhazmat.2011.11.073

Dahrazma, B. Mulligan, C. N. 2007. Investigation of the removal of heavy metals from sediments using rhamnolipid in a continuous flow configuration, Chemosphere 69: 705-711. https://doi.org/10.1016/j.chemosphere.2007.05.037

Dahrazma, B.; Mulligan, C. N. 2006. Evaluation of the removal of heavy metals from contaminated sediment in continuous flow tests with selective sequential extraction, Journal of ASTM International 3: 200-209. https://doi.org/10.1520/JAI13337

Di Palma, L.; Gueye, M. T.; Petrucci, E. 2015. Hexavalent chromium reduction in contaminated soil: a comparison between ferrous sulphate and nanoscale zero-valentiron, Journal of Hazardous Materials 281: 70-76. https://doi.org/10.1016/j.jhazmat.2014.07.058

Doelsh, E.; Moussard, G.; Macary, H. S. 2008. Fractionation of tropical soilborne heavy metals-comparison of two sequential extraction procedure, Geoderma 143: 168-179. https://doi.org/10.1016/j.geoderma.2007.10.027

Ebrahimi, A.; Ehteshami, M.; Dahrazma, B. 2015. Biosorption of Cd (II) from aqueous solutions using Crataegus Oxyacantha stone and Punicagranatum seed, Desalination and Water Treatment 57(20): 9354-9365.

https://doi.org/10.1080/19443994.2015.1029005

Elliott, D.; Zhang, W. X. 2001. Field assessment of nanoscale bimetallic particles for groundwater treatment, Environmental Science and Technology 35: 4922-4926.

https://doi.org/10.1021/es0108584

Fan, W.; Jia, Y.; Li, X.; Jiang, W.; Lu, L. 2012. Phytoavailability and geospeciation of cadmium in contaminated soil remediated by Rhodobacter sphaeroides, Chemosphere 88: 751-756. https://doi.org/10.1016/j.chemosphere.2012.04.047

Filgueiras, A. V.; Lavilla, I.; Bendicho, C. 2002. Chemical sequential extraction for metal partitioning in environmental solid samples, Journal of Environmentla Monitoring 4: 823-857. https://doi.org/10.1039/b207574c

Ge, F.; Li, M. M.; Ye, H.; Zhao, B. X. 2012. Effective removal of heavy metal ions $\mathrm{Cd}^{2+}, \mathrm{Zn}^{2+}, \mathrm{Pb}^{2+}, \mathrm{Cu}^{2+}$ from aqueous solution by polymer-modified magnetic nanoparticles, Journal of Hazardous Materials 211-212: 366-372. https://doi.org/10.1016/j.jhazmat.2011.12.013

Giannis, A.; Gidarakos, E. 2005. Washing enhanced electrokinetic remediation for removal cadmium from real contaminated soil, Journal of Hazardous Materials 123: 165-175. https://doi.org/10.1016/j.jhazmat.2005.03.050

Gleyzes, C.; Tellier, S.; Astruc, M. 2002. Fractionation studies of trace elements in contaminated soils and sediments: a review of sequential extraction procedures, TrAC Trends in Analytical Chemistry 21: 451-466. https://doi.org/10.1016/S0165-9936(02)00603-9

Golzar, M.; Saghravani, S. F.; Azhdari Moghaddam, M. 2014. Experimental study and numerical solution of poly acrylic acid supported magnetite nanoparticles transport in a one-dimensional porous media, Advances in Materials Science and Engineering, Article ID 864068. http://dx.doi.org/10.1155/2014/864068

Guler, U. A. 20116. Removal of tetracycline from aqueous solutions using nanoscale zero valent iron and functional pumice modified nanoscale zero valent iron, Journal of Environmental Engineering and Landscape Management 1-11.

Guo, X.; Wei, Z.; Wu, Q.; Li, Ch.; Qian, T.; Zheng, W. 2016. Effect of soil washing with only chelators or combining with ferric chloride on soil heavy metal removal and phytoavailability: field experiments, Chemosphere 147: 412-419. https://doi.org/10.1016/j.chemosphere.2015.12.087

Gzar, H. A.; Abdul-Hameed, A. S.; Younus Yahya, A. 2014. Extraction of lead, cadmium and nickel from contaminated soil using acetic acid, Journal of Soil Science 4: 207-214. https://doi.org/10.4236/ojss.2014.46023

He, F.; Zhao, D. Y. 2005. Preparation and characterization of a new class of starch-stabilized biometallic nanoparticles for degration of chlorinated hydrocarbons in water, Environmental Science and Technology 39: 3314-3320.

https://doi.org/10.1021/es048743y

Hetzer, A.; Daughney, C. J.; Morgan, H. W. 2006. Cadmium ion biosorption by the thermophilic bacteria Geobacillus stearothermophilus and G. thermocatenulatus, Applied and Environmental Microbiology 72: 4020-4027. https://doi.org/10.1128/AEM.00295-06

Hseu, Z. Y. 2006. Concentration and distribution of chromium and nickel fractions along a serpentinitic toposequence, Soil Science 171(4): 341-353. https://doi.org/10.1097/01.ss.0000209354.68783.f3

Huang, Z. Y.; Li, J.; Cao, Y. L.; Cai, C.; Zhang, Z. 2016. Behaviors of exogenous $\mathrm{Pb}$ in $\mathrm{P}$-based Amended soil investigated with isotopic labeling method coupled with tessier approach, Geoderma 264: 126-131. https://doi.org/10.1016/j.geoderma.2015.10.013

Huang, Z. Y.; Qin, D. P.; Zeng, X. C.; Li, J.; Cao, Y.; Cai, C. 2012. Species distribution and potential bioavailability of exogenous $\mathrm{Hg}$ (II) in vegetable-growing soil investigated with a modified tessier scheme coupled with isotopic labeling technique, Geoderma 189: 243-249. https://doi.org/10.1016/j.geoderma.2012.05.018

Kanel, S. R.; Nepal, D.; Manning, B.; Choi, H. 2007. Transport of surface-modified iron nanoparticle in porous media and application to arsenic (III) remediation, Journal of Nanoparticle Research 9: 725-735. https://doi.org/10.1007/s11051-007-9225-7

Lao, U. L.; Chen, A.; Matsumoto, M. R.; Mulchandani, A.; Chen, W. 2007. Cadmium removal from contaminated soil by thermally responsive elastin (ELPEC20) biopolymers, Biotechnol and Bioengin 98: 349-55. https://doi.org/10.1002/bit.21478

Lee, S. K.; Choi, H. S. 2001. Spectrophotometric determination of cadmium and copper with ammonium pyrrolidinedithiocarbamate in nonionic tween 80 micellar media, Bulletin of the Korean Chemical Society 5: 463-466.

Li, J.; Sun, Y.; Yin, Y.; Ji, R.; Wu, J.; Wang, X.; Guo, H. 2010. Ethyl lactate-EDTA composite system enhances the remediation of the cadmium-contaminated soil by autochthonous willow (Salix $\times$ aureo-pendula CL 'J1011') in the lower reaches of the Yangtze River, Journal of Hazardous Materials 181(1): 673-678. https://doi.org/10.1016/j.jhazmat.2010.05.065

Liu, Y. Q.; Majetic, S. A.; Lowry, G. V. 2005. TCE dechlorination rates, pathways, and efficiency of nanoscale iron particles with different properties, Environmental Science and Technology 39: 1338-1345. https://doi.org/10.1021/es049195r

Liu. H.; Chen, T.; Xie, Q.; Zou, X. 2015. The functionalization of limonite to prepare NZVI and its application in decomposition of p-nitrophenol, Journal of Nanoparticle Research 17: 374-391. https://doi.org/10.1007/s11051-015-3171-6

Martínez-Fernández, D.; Bingöl, D.; Komárek, M. 2014. Trace elements and nutrients adsorption onto nano-maghemite in 
a contaminated-soil solution: a geochemical/statistical approach, Journal of Hazardous Materials 276: 271-277.

https://doi.org/10.1016/j.jhazmat.2014.05.043

McLaren, R. G.; Crawford, D. 1973. Studies on soil copper: the fractionation of copper in soils, Journal of Soil Science 24: 172-179. https://doi.org/10.1111/j.1365-2389.1973.tb00753.x

Mulligan, C. N.; Dahrazma, B. 2003. Use of selective sequential extraction for the remediation of contaminated sediments, ASTM STP 1442: 208-223. https://doi.org/10.1520/STP11564S

Nasiri, J.; Gholami, A.; Ebrahimi, P. 2013. Removal of Cadmium from soil resources using stabilized Zero-Valent Iron Nanoparticles, Journal of Civil Engineering and Urbanism 3(6): 338-341.

Nutt, M. O.; Hughes, J. B.; Wong, M. S. 2005. Designing Pdon-Au bimetallic nanoparticle catalysts for trichloroethene hydrodechlorination, Environmental Science and Technology 39: 1346-1353. https://doi.org/10.1021/es048560b

Ozbas, E. E.; Balkaya, N. 2014. Removal of heavy metals (Cu, Ni, $\mathrm{Zn}, \mathrm{Pb}, \mathrm{Cd}$ ) from compost by molasses hydrolysate, Journal of Environmental Engineering and Landscape Management 22(4): 301-310. https://doi.org/10.3846/16486897.2014.919922

Ozturk, A.; Yarci, C.; Ozyigit, I. I. 2017. Assessment of heavy metal pollution in Istanbul using plant (Celtis australis L.) and soil assays, Journal of Biotechnology and Biotechnological Equipment 38(4): 1-7. https://doi.org/10.1080/13102818.2017.1353922

Pandey, M.; Pandey, A. K.; Mishra, A.; Tripathi, B. D. 2015. Assessment of metal species in river Ganga sediment at Varanasi, India using sequential extraction procedure and SEMEDS, Chemosphere 134: 466-474.

https://doi.org/10.1016/j.chemosphere.2015.04.047

Quezada-Hinojosa, R. P.; Folkmi, K. B.; Verrecchia, E.; Adatte, T; Matera, V. 2015b. Speciation and multivariable analyses of geogenic cadmium in soils at Le Gurnigel, Swiss Jura Mountains, Catena 125: 10-32.

https://doi.org/10.1016/j.catena.2014.10.003

Quezada-Hinojosa, R.; Folkmi, K. B.; Gillet, F.; Matera, V. $2015 \mathrm{a}$. Cadmium accumulation in six common plant species associated with soils containing high geogenic cadmium concentrations at Le Gurnigel Swiss Jura Mountains, Catena 124: 85-96. https://doi.org/10.1016/j.catena.2014.09.007

Quintelas, C.; Rocha, Z.; Silva, B.; Fonseca, B.; Figueiredo, H.; Tavares, T. 2009. Removal of Cd(II), Cr(VI), Fe(III) and Ni(II) from aqueous solutions by an E. coli biofilm supported on kaolin, Chemical Engineering Journal 149: 319-324. https://doi.org/10.1016/j.cej.2008.11.025

Reddy, K. R. 2010. Nanotechnology for site remediation: dehalogenation of organic pollutants in soils and groundwater by nanoscale iron particles, in $6^{\text {th }}$ International Congress on Environmental Geotechnics, 30 Sep 2009, New Delhi, India.

Rico, M. I.; Alvarez, J. M.; Lopez-Valdivia, L. M.; Novillo, J.; Obrador, A. 2009. Manganese and Zinc in acidic agricultural soils from central Spain: distribution and phytoavailability prediction with chemical extraction tests, Soil Science 174(2): 94-104. https://doi.org/10.1097/SS.0b013e3181975058

Shafai, SH.; Fotovat, A.; Khorasani, R. 2012. Effect of nanoscale Zero-Valent Iron (nZVI) on heavy metals availability in a calcareous soil, Journal of Water and Soil 26: 586-896.

Strachel, R.; Wyszkowska, J.; Baćmaga, M. 2017. The effect of nitrogen on the microbiological and biochemical properties of zinc-contaminated soil, Journal of Environmental Engineering and Landscape Management 25(1): 13-22.

https://doi.org/10.3846/16486897.2016.1184154
Sun, Y. P.; Li, X. O.; Sao, J.; Zhang, W. X.; Wang, H. P. 2006. Characterization of zero-valent iron nanoparticles, Advances in Colloid and Interface Science 120: 47-56.

https://doi.org/10.1016/j.cis.2006.03.001

Tessier, A.; Campbell, P. G. C.; Bisson, M. 1979. Sequential extraction procedure for the speciation of particulate trace metals. Analytical Chemistry 51: 844-851.

https://doi.org/10.1021/ac50043a017

Tokalioglu, S.; Kartal, S.; Birol, G. 2003. Application of a treestage sequential extraction procedure for the determination of extractable metal contents in highway soils, Turkish Journal of Chemistry 27: 333-346.

Tombacz, E. 2002. Adsorption from electrolyte solutions, Surfactant science series 107: 711-742.

Tombacz, E.; Majzik, A.; Horvat, Z.; Illes, E. 2006. Magnetite in aqueous medium: coating its surface and surface coated with it, Romanian Reports in physics 58(3): 281-286.

Uduma, A. U.; Jimoh, W. L. O. 2013. Sequential extraction procedure for partitioning of Lead, Copper, Cadmium, Chromium, and Zinc in contaminated Arable soils of Nigeria, American Journal of Environment, Energy and Power Research 1: 186-208.

Vasarevičius, S.; Skripkiūnas, G.; Danila, V. 2016. Experimental research into leaching of metals from immobilized CIS solar module waste, Journal of Environmental Engineering and Landscape Management 24(4): 269-277. https://doi.org/10.3846/16486897.2016.1198262

Wang, C. B.; Zhang, W. X. 1997. Synthesizing nanoscale iron particles for rapid and complete dechlorination of TCE and PCBs, Environmental Science and Technology 31: 2154-2156. https://doi.org/10.1021/es970039c

Xu, J.; Dozier, A.; Bhattacharyya, D. 2005. Synthesis of nanoscale bimetallic particles in polyelectrolyte membrane matrix for reductive transformation of halogenated organic compounds, Journal of Nanoparticle Research 7: 449-461. https://doi.org/10.1007/s11051-005-4273-3

Yong, R. N.; Galvez-Cloutier, R.; Phadungchewit, Y. 1993. Selective sequential extraction analysis of heavy metal retention in soil, Canadian Geotechnical Journal 30: 834-847. https://doi.org/10.1139/t93-074

Yuan, S.; Long, H.; Xie, W.; Liao, P.; Tong, M. 2012. Electrokinetic of CMC-stabilized Pd/Fe nanoparticles for the remediation of PCB-contaminated soil, Geoderma 185-186: 18-25. https://doi.org/10.1016/j.geoderma.2012.03.028

Zak, S.; Raukyte-Zak, T.; Laurinavicius, A. 2013. The influence of treated oleo-chemical wastewater applications on the metal speciation forms in soils, Journal of Environmental Engineering and Landscape Management, 21 (2): 85-95. http://dx.doi.org/10.3846/16486897.2013.773259

Zaleckas, E.; Paulauskas, V.; Sendžikienè, E. 2013. Fractionation of heavy metals in sewage sludge and their removal using low-molecular-weight organic acids, Journal of Environmental Engineering and Landscape Management 21(3): 189-198. https://doi.org/10.3846/16486897.2012.695734

Zhang, W. X. 2003. Nanoscale iron particles for environmental remediation: An overview, Journal of Nanoparticle Research 5: 323-332. https://doi.org/10.1023/A:1025520116015

Zhao, X.; Jiang, T.; Du, B. 2014. Effect of organic matter and calcium carbonate on behaviors of cadmium adsorption-desorption on/from purple paddy soils, Chemosphere 99: 41-48. https://doi.org/10.1016/j.chemosphere.2013.09.030 